\title{
WALT AND SIR WALTER OR THE BARD AND THE BART.: Balladeers
}

JOHN ENGELL

JUSTIN KAPLAN'S BIOGRAPHY of Whitman begins with a selection of literary fragments, shards of Whitman's writings, which offer vague clues to his development as a man and his transformation as a poet. Of one such fragment, Kaplan tells us, "Naming Homer, Shakespeare, and Sir Walter Scott, all 'masters' after their own kind, the outsetting bard had declared, 'I will be also a master after my own kind, making the poems of emotions, as they pass or stay, the poems of freedom, and the exposé of personality-singing in high tones democracy and the New World of it through These States." '1 Homer and Shakespeare are expected tutelary deities, but Scott seems slightly less so, even conceding his enormous popularity in the first half of the nineteenth century. In fact, Whitman not infrequently expressed contempt for the political and social implications of Scott's work, writing as early as 1846 in the Brooklyn Daily Eagle, "Walter Scott, Croly, Alison, Southey, and many others well known in America, exercise an evil influence through their books, in more than one respect; for they laugh to scorn the idea of republican freedom and virtue."2 Paul Zweig, speaking of Whitman's middle years beginning in the late 1840s, insists that, "At the time [Whitman] deplored the novels of Walter Scott which he had loved a dozen years before and would read again with pleasure almost half a century later. Scott's greatness, like Shakespeare's, was marred for Whitman by his 'feudal' mentality and his condescension to the common man. He was 'dangerous' to democrats." ${ }^{3}$ Yet, as Zweig admits, Whitman's admiration was renewed. The aged poet again acknowledged Scott as a mentor. "How much I am indebted to Scott," Whitman exclaimed to Horace Traubel, "no one can tell-I couldn't tell it myself-but it has permeated me through and through. If you could reduce the Leaves to their elements you would see Scott unmistakably active at the roots."4 Later in the same month Whitman spoke of Scott again: "I prefer the Border Minstrelsy to anything else: it is to me the richest vein he worked."5

Why, we wonder, this admiration for Scott, both early and late in Whitman's life? Surely two writers could not be, at first glance, more unlike. Scott's poetic manner, with its extremely regular meter and inevitable rhyme, seems completely foreign to the irregular, surprising lines of Whitman; and Scott's chivalric-feudal manner, both in fiction and poetry, is, as Whitman and Zweig point out, the opposite of the American bard's. Floyd Stovall, of course, has examined the "long foreground" Emerson wrote of, but even he has not been able to attribute any direct influence to Scott. Of 
Whitman Stovall writes, "He loved the romantic past, recreated in music by Donizetti and his contemporaries, in drama by Shakespeare, and in fiction by Walter Scott, and doubtless it became a part of him and entered into the making of Leaves of Grass in subtle ways; yet it was his intention to make his poem primarily the voice of democracy expressed through an individual personality in his own time and place."6 As Stovall implies, any statement about the influence the poet seems to value so highly must be speculative; but the critics who have speculated systematically on the matter seem to be few or none. What are we to make of Whitman's early admiration for Scott; of his apparent turning away from the baronet's influence; of his later reaffirmation of his debt to the Scotsman? Indeed, what in Scott's work may have influenced Whitman, and how? What elements of Scott have "permeated [Whitman] through and through"? What elements in Leaves proclaim Scott "unmistakably active at the roots"? These questions are too curious to leave unexamined.

A logical first step in this speculation is to discover what works of Scott Whitman read. Apparently, Stovall notes, he started with the romances and moved on to the poetry. ${ }^{7}$ Whitman, in "A Backward Glance O'er Travel'd Roads" tells us:

Along in my sixteenth year I had become possessor of a stout, well-cramm'd one thousand page octavo volume (I have it yet,) containing Walter Scott's poetry entire-an inexhaustible mine and treasury of poetic forage (especially the endless forests and jungles of notes)-has been so to me for fifty years, and remains so to this day.

Whitman's note at the foot of the page reads:

Sir Walter Scott's Complete Poems; especially including Border Minstrelsy; then Sir Tristrem; Lay of the Last Minstrel; . . . various Introductions, endless interesting Notes, and Essays on Poetry, Romance, \&c.

Lockhart's 1833 (or '34) edition with Scott's latest and copious revisions and annotations. (All the poems were thoroughly read by me, but the ballads of the Border Minstrelsy over and over again. $)^{8}$

Traubel reports on 30 May 1888, "W[hitman] showed us a Walter Scott volume-an edition of 1833 -with a title page drawn and written in his own hand, in red and black ink." Stovall speculates that this was only volume one of a seven-volume set of Scott's Complete Works, published in New York in 1833 by Leavett \& Allen. In fact, Whitman's edition of Scott's poetry is part of the Feinberg collection at the Library of Congress, and it proves to be the first volume of another seven-volume set published in New York by Conner \& Cooke in $1833 .{ }^{10}$ This volume is remarkable for several particulars.

Immediately before the title page Whitman has written in a large hand, "Walt Whitman 1835-1887" and, using another writing instrument, "and on to '91." These dates correspond to those in Traubel; Whitman acquired the 
volume when he was only sixteen and returned to it with renewed interest late in his life. The date 1835 may explain missing pages in the volume. All of the title page (i) except the bottom inch listing publisher, place, and date is gone; so too is the single page listing Contents (iii) and the "Advertisement to the American Edition" (v-vi) signed by Conner and Cooke. Missing as well is the first of five miscellaneous prose works concluding the volume, "Paul's Letters to his Kinsfolk." Whitman may have cut out these sections himself; it seems more likely that he acquired the volume used and abused and at some point penned his own title page and Table of Contents to replace what was missing. In the actual Conner \& Cooke volume the Contents lists only six items, "Poetical Works" and the five prose pieces beginning with "Paul's Letters." Whitman's handwritten Table of Contents is five pages long and lists every one of the nearly one hundred poems in the Minstrelsy of the Scottish Border save a single piece that he apparently overlooked. This list makes up three-quarters of the entire Contents and indicates, it would appear, the American bard's chief interest in the volume, namely Scott's collection of the ballads of the folk.

Such a conjecture is strengthened by the nature of the newspaper articles and reviews Whitman either taped or inserted in the volume. In the front of the volume is an undated and unenlightening article, "Sons of St. Patrick Toast the Irish Poet," concerning a gathering of the St. Patrick Society at the Clarendon Hotel to toast Thomas Moore. Of greater interest is another undated newspaper clipping, a review of "Old Ballads. A Selection From French Popular Ballads Edited, with Introduction and Notes by Thomas Frederick Crane." This volume was, in fact, published by G. P. Putnam's Sons in 1891, less than a year before Whitman's death. Surprisingly, Whitman has written "Walter," rather than "Walt," at the top of this clipping. A fragment of a headline including the name Thomas Moore is attached to the two aforementioned articles, once again signed "Walter." These signatures - so startling late in Whitman's career -seem to be attempts, perhaps playful ones, to reproduce the signature of Scott which appears under his picture immediately preceding the title page. Taped opposite the second page of Whitman's Table of Contents is an article titled, "'Ballad Poetry.'-talk by Rev. Richard G. Moulton on 'Ballad Poetry' (Chickering Hall last evening)." In brown pencil Whitman has written "Boston Trans. Jan:6 '90." Finally, between pages fourteen and fifteen Whitman has inserted another review: "Professor Child's Collection of Ballads" and written on its margin "Critic Aug. 22 '85." In every case these articles and reviews refer to the ballad and suggest that, at least late in his life, Whitman was deeply interested in the form.

Marginalia and underlinings in the volume are sparse. ${ }^{11}$ Most appear between pages 1 and 238, the Border Minstrelsy section including also Lockhart's one-page "Advertisement" (3) for the Border Minstrelsy; and Scott's essay, "Introductory Remarks on Popular Poetry" (5-16), which he wrote in 1830 for the second issue of his Poetical Works by Archibald Constable Co., 
and which is among the "latest and copious revisions" Whitman refers to in "A Backward Glance." Many of Whitman's marginal notations and underlinings hold little interest. But several are extraordinarily suggestive. Perhaps the most significant occur in Lockhart's brief "Advertisement." Lockhart begins:

Two volumes of the Minstrelsy of the Scottish Border were published in 1802; - a third followed in 1803; and in the course of subsequent editions, the arrangement of the ballads underwent various changes, and numerous additions were made to the Notes. Sir Walter Scott drew up, in March, 1830, the "Introductory Remarks on Popular Poetry," which appear at the head of the present volume, and an "Essay on Imitations of the Ancient Ballad," which will be given at the close of the Border Minstrelsy. He kept by him, as long as his health permitted him to continue his literary pursuits, an inter-leaved copy of the Collection by which his name was first established, inserting various readings as chance threw them in his way, and enriching his annotations with whatever new lights conversation or books supplied. The Work is now printed according to the copy thus finally corrected. . . . (3).

In the margin to the left of the first sentence quoted above Whitman has written "WS aged 30-(31)"; in the same margin next to the last phrase Whitman has noted "aged 55-60." Moreover, he has drawn a squiggly and heavily accented line in pencil next to the last two sentences beginning, "He kept by him ..." and has underlined the final words "The Work is now printed according to the copy thus finally corrected."

\section{Later in the "Advertisement" Lockhart writes:}

One of the Reviewers of the Minstrelsy, when it first appeared, said, "In this collection are the materials for scores of metrical romances." This was a prophetic critic. In the text and notes of this early publication, we can now trace the primary incident, or broad outline, of almost every romance, whether in verse or in prose, which Sir Walter Scott built in after life on the history or traditions of his country (3).

Again, Whitman has scored this passage with an emphatic line in the left margin. And finally, at the conclusion of the essay, Whitman has underlined these words, "It [the Border Minstrelsy] is truly a patriot's legacy to posterity" (3).

Taken together, Lockhart's comments about the Border Minstrelsy and Whitman's response to them suggest a clear link between the organic growth of Scott's ballads by the folk and the organic evolution of Whitman's ballads about the folk, Leaves of Grass. Whitman nowhere indicates when he made the marginal notations and underlinings on this "Advertisement"; it may have been late in his career. He may have been recognizing, in retrospect, an affinity between the Border Minstrelsy and Leaves of Grass as if to say "WW aged 36" next to a description of the 1855 edition and "WW aged 72 " beside the 1891 edition. It is possible, of course, that these notes were made as early as 1835; but in all likelihood any date between 1855 and 1891 is more probable. Whatever the date of these notations, Whitman unquestionably recog- 
nized in Border Minstrelsy and in its relation to the career of Scott and the history of Scotland a parallel to Leaves of Grass in relation to Whitman's career and the history of the United States. Like Border Minstrelsy, Leaves of Grass was its author's first volume of poetry. In both collections, poems were rearranged, revised, and added for subsequent editions. Each edition of Leaves of Grass was "printed according to the copy thus finally corrected." Whitman used the first edition of Leaves of Grass as the inspiration for all his future poetic work. And, of greatest importance, Whitman envisioned his evolving collection as "a patriot's legacy to posterity."

In his "Introductory Remarks on Popular Poetry," Scott developed (if not pioneered) a theory of national poetic expression, reflecting in part the nationalistic political movement and rediscovery of native forms which engrossed Europe in the late eighteenth and nineteenth centuries. Scott writes, "To the lovers and admirers of poetry as an art, it cannot be uninteresting to have a glimpse of the National Muse in her cradle" (6). The poems of Scott's Border Minstrelsy, according to this theory, show that infant muse. Scott suggests, "But it is evident that, though poetry seems a plant proper to almost all soils, yet not only is it of various kinds, according to the climate and country in which it has its origin, but the poetry of different nations differs still more widely in the degree of excellence which it attains" (6). Homer is the representative type of the national poet for Scott, just as he, along with Scott himself, was for Whitman. In one of his few notations on this essay, Whitman has scored the right-hand margin beside this passage:

Indeed, though much must be ascribed to the riches of his own individual genius, the poetry of Homer argues a degree of perfection in an art which practice had already rendered regular, and concerning which, his frequent mention of the bards, or chanters of poetry, indicated plainly that it was studied by many, and known and admired by all (5).

Here it seems we have, if not a precise parallel to Whitman's verse, at least a possible source for much of his thinking about poetry. Barlow had written his American epic the Columbiad and its predecessor The Vision of Columbus in heroic couplets, as Timothy Dwight had done in The Conquest of Canaan. This was a neoclassical form borrowed from Dryden and Pope. Longfellow in Evangeline - a poem Whitman admired - tried to graft classical hexameters on to his native stock, but the graft did not take. Even the primitive tales told by Native Americans seemed too literary when turned into Hiawatha (published the same year as the first edition of Leaves of Grass). The problem seems to be, as Robert Frost put it, that the land was ours before we were the land's; the National Muse did not develop with the country. Rather, it was wrenched, fully grown, from the forehead of each aspiring poet. Whitman, however, tried turning Scott's theory into practice, by making the kind of poetry that would suit the soil of the United States. He declares that purpose often enough, at least. Both Muse and infant, Whitman bawled his poems in the American idiom. But the source of these poems was 
not just Walt Whitman, but Walt Whitman, American. As his identity became somehow synonymous with the national identity, so the poetry of his self became the poetry of the nation.

In his essay Scott also limns the conditions necessary for the outsetting poet:

A keen and active power of observation, capable of perceiving at a glance the leading circumstances from which the incident described derives its character; quick and powerful feelings, to enable the bard to comprehend and delineate those of the actors in his piece; and a command of language, alternately soft and elevated, and suited to express the conceptions which he had formed in his mind, are all necessary to eminence in the poetical art (5).

Observation, empathy, and decorum of language are thus the three prerequisites for the aspiring poet, according to Scott. Whitman, at first, tried to follow these dicta, with results that were, at best, pallid. In Leaves of Grass, however, he combined the first two by seeing and becoming simultaneously - to observe is to empathize in this method-and invented a decorum of his own. Earlier in his essay, Scott speaks of the primitive poet, who refines

the ordinary speech which forms the vehicle of social communication betwixt him and his brethren, until, by a more ornate diction, modulated by certain rules ... . he obtains a dialect more solemn in expression, to record the laws and exploits of his tribe, or more sweet in sound, in which to plead his own cause to his mistress (5).

Indeed, Whitman refined the "ordinary speech ... of social communication" until it could become more solemn in sound, but his sound remains much different from that envisioned by Scott.

Whitman, then, absorbed Scott's theories of poetry, if only to reinterpret or reject some of them as he discovered his own voice. But Whitman also admired Scott's practice. In an interview with Harper's Weekly published on 23 April 1887, Whitman relates that "[t]he only poetry that had nourished him was Sir Walter Scott's Border Minstrelsy, particularly Sir Walter's memoranda of interviews with old Scotsmen and Scotswomen respecting the folklore of their earlier days."12 Scott's Border Minstrelsy is a collection of folk ballads, recorded and annotated by Scott himself. The idea of the poet actually going to the people for his poems must have inspired the young Whitman. As Scott collected the ballads of Scotland and made up his own facsimiles, so Whitman heard America singing and recorded the songs through his own voice.

But Whitman's poetry becomes a poetry of the people in a way that Scott's is not. For if Scott's collections of folklore relate his countrymen's legendary beliefs, Whitman's verse stops short of that: it is not a collection of folklore, but rather a collection of folk-a poetry of the people composed of, though not by, the people themselves. Thus, Whitman becomes the poet who observes and records the "blab of the pave"; 13 who sees the "boatmen 
and the clam-diggers," the "butcher-boy" putting off his "killing clothes," the "Blacksmiths with grimed and hairy chests," the "negro" whose glance is "calm and commanding," and all the vast catalogue of pursuits in Section 15 of "Song of Myself," beginning "The pure contralto sings in the organ loft," and moving through the carpenter, the duck-shooter, the farmer, the lunatic, the connoisseur, the one-year wife, the bride, the opium-eater, the President, and many more, until the catalogue reaches Whitman himself, who concludes

And these tend inward to me, and I tend outward to them,

And such as it is to be of these more or less I am,

And of these one and all I weave the song of myself.

Thus Whitman includes both himself among the folk he observes, and the people in himself. He has become not only a representative man, a Homer or a Scott, but an inclusive man. The random identification of the people the poet envisions becomes not only an exposé of Whitman's personality, but through the poet, who records them and himself in them, an exposé of democracy, of these United States.

Whitman replaces the feudal history and chivalric legends found in Scott with his own personal history. In "Poetry To-day in America," he decries Scott's work for exhaling "that principle of caste which we Americans have come on earth to destroy."14 America has little use for the feudal past; Whitman's poetry is of the present and the future. Instead of a loyal peasantry, doffing their caps to the laird, Whitman sees a President tipping his hat to the people, or farmers who remove their hats for no one. By positing himself as a corporate body, composed somehow of the parts of the nation, he eliminates the need to record either a mythic, legendary, or actual national past, for his personal past substitutes. Starting out at Paumanok, he is the national muse, in its cradle, endlessly chanting. Just as Scott turned toward the people to explore the past and, in the process, created a new national identity and selfawareness, so Whitman turns toward the people and affirms the future in order to accomplish the same ends. And, surely, the wonderful aptness of Scott's name was not lost on Whitman; the identification of man and country here was virtually complete; as Scott recorded the lore of the "Scotts" (his spelling), the identity of the nation became bound up, eponymously and otherwise, with his own. Scott was the representative Scot.

But Scott's importance for Whitman may have gone beyond the baronet's theory of national verse or his example as a kind of national poet. Several examples of Whitman's verse published in the period before Leaves of Grass are in the traditional ballad form. "Young Grimes" and "The Playground" sentimentally affirm the folk pieties of thrift, wholesomeness, and happiness, while "The Inca's Daughter" offers a dramatic incident like in kind to those in Scott's Border Minstrelsy. This period of very traditional ballad formulation seems to have been exhausted during Whitman's early years as a writer; 
perhaps, however, vestiges of Scott's influence may be found in Whitman's mature work as well.

Certainly the form of the ballad has been eliminated in Leaves of Grass; gone are the familiar 4-3-4-3 stanzas with their alternate rhyme. And, as previously noted, Whitman also eliminates the traditional chivalric trappings of Scott's minstrelsy. What this leaves is what Walter Morris Hart describes as a dramatic narrative method, often tragic, dealing with a "situation full of emotional significance." 15 Hart names other characteristics: the ballad begins in the middle of the action, or even as it is concluding; the actual narrative flow is hinted at through indirection and allusion or the central motive is held until the close; the goal of the balladist is "simple and single; he presses constantly forward toward [his] goal."16 Hart's description of "Lord Randal" is particularly evocative:

"Lord Randal" exemplifies, also, other ballad characteristics - the selection of a telling situation, not action, but the most dramatic point before and after action. It is a concrete and suggestive dialogue, revealing the fact that Lord Randal had been poisoned, and suggesting pretty definitely that he is about to die. All else is mystery, or is taken for granted. ${ }^{17}$

This method-the ballad's way of telling a story, shorn of all its obvious brands and blazons - can be used to describe some of Whitman's poetry as well. In Section 11 of "Song of Myself," for example, Whitman describes the twenty-eight young men bathing as the twenty-eight-year-old woman watches from the window. This is indeed a "telling situation, not action but the most dramatic moment before and after action." The narrative flow is indirect: the lady watches, and in her imagination (and the poet's) splashes with the bathers. The young men remain unaware. We know the woman is twenty-eight, handsome, well-to-do; but who she is or why she is "so lonesome," or, indeed, any other salient characteristic about either the watcher or the bathers is left unspoken. The poem begins in the middle of the action, and it is up to the reader to conclude it, just as it is up to the hearer to decide for himself that Lord Randal dies after the ballad is over.

This particular fragment uses repetition in a way which seems more like the incremental repetition of the traditional ballad and less like Whitman's usual all-purpose cable-stitch epanaphora. Indeed, the first three lines sound as though they could easily be sung. The use of the supernatural is another typical ballad motif, which may find its analog in this poem in the almost palpably physical psychic projection of the woman as she joins the bathers in her mind-although the poet tells us he sees her there.

Other parts of "Song of Myself" offer additional traditional ballad arrangements and subjects. Section 34 presents the poet telling his audience (like a ballad-singer addressing his audience) of the "murder of the four hundred and twelve young men." Battle is not the subject of this segment, but betrayal after the battle; the young men have surrendered honorably, and they are massacred. Whitman writes: 
They were the glory of the race of rangers,

Matchless with horse, rifle, song, supper, courtship,

Large, turbulent, generous, handsome, proud, and affectionate,

Bearded, sunburnt, drest in the free costume of hunters,

Not a single one over thirty years of age.

These are the true tones, not of the folk ballad, but of the balladeer-poet. Whitman, in the traditional manner, exaggerates the virtues of his heroes in order to increase the pathos of his story. The manner of the execution and the helpless struggles of the victims are lingered on momentarily, and then the poet stops dramatically with the lighting of the heroes' funeral pyre.

The two parts immediately following Section 34 tell of a sea-fight, another frequent ballad subject, though Whitman is diffuse in his treatment of it. In earlier editions of Leaves, Whitman, the poet, recounted this story. But after 1867 he puts the story, ballad-like, in the mouth of his grandfather, who begins with a faint echo of the rhyme and meter of the traditional ballad.

Our foe was no skulk in his ship I tell you, (said he,)

His was the surly English pluck, and there is no tougher or truer, and never was, and never will be ...

The rhymes skulk/pluck and he/be and the loping rhythm trigger expectations of the customary ballad form. These expectations, however, are not fulfilled by the poem. Whitman proceeds through short descriptive passages, and adopts what sounds like the beginning of a refrain - "Fighting at sundown, fighting at dark"-but quickly abandons it, too. Drama drains from the poem; contrasted with these spurts of early rhythm is the oddly flat finale: "One of the pumps has been shot away, it is generally thought we are sinking." And the poem concludes with an oddly anti-climactical climax: "Toward twelve there in the beams of the moon they surrender to us." It is as if Whitman had unconsciously begun to write a ballad then, suddenly aware of this tendency and unwilling to employ the ancient and often chivalric form, abandoned it for a sort of desultory realism.

Whitman's copy of Scott's poetry suggests other ways, very broad in outline, in which he may have been indebted to Border Minstrelsy and to the ballad. In his Table of Contents and in his infrequent textual notations, Whitman emphasizes Scott's division of the ballads into three types: "Historical" ballads dealing primarily with war and feats of heroism; "Romantic" ballads relating tales of love, usually unrequited or tragic love; and "Imitations of the Ancient Ballad," Scott's attempts to render ballad subjects in his own words. "Song of Myself" and indeed all of Leaves of Grass may be loosely divided into parts or groupings dealing with either "Historical" or "Romantic" subjects as defined by the ballad tradition. Thus, for example, Sections 34, 35, and 36 of "Song of Myself" are in subject traditional "Historical" ballads while Sections 7, 11, 24, 31, and many others approximate the "Romantic" 
ballad though their romance is frequently far more metaphysical and transcendental than anything Scott or his folk would have entertained. Moreover, the Calamus and Children of Adam groupings in rather different ways can be called "Romantic" whereas the Drum Taps section is clearly "Historical" in the sense Scott uses this word to describe a particular type of ballad. In both instances-Historical and Romantic-the ballad tradition may help to explain the surprising and frequent presence of death and unfulfilled love in Whitman's generally optimistic verse. Bittersweet sentiments, loss, sorrow, defeat-these permeate both the "Historical" and "Romantic" ballads of Border Minstrelsy. They also permeate Leaves of Grass. In the third section of Border Minstrelsy, the "Imitations of the Ancient Ballad," Whitman has noted in the right-hand margin beside two poems, "one of the earliest of WS's ballads" $\mid(203,207)$. These pieces, "Glenfinlas; or Lord Ronald's Cormach" and "The Eve of St. John" must have represented, for the American bard, something of the same process in which he was engaged. For here Scott attempts in his own language and construction to approximate the form and substance of the ancient ballad. Whitman's manner is never so formal, his subjects never so feudal. But Leaves of Grass is, after all, an "Imitation" of the ballads of American folk-ballads of the present, the future, the past, the people, and the seer made one.

Other clues to Whitman's understanding of and reliance on the ballad tradition may be contained in several of the newspaper clippings he included in Scott's volume of poetry. In the article on "Professor Child's Collection of Ballads," the reviewer emphasizes how these poems reveal "the actualities of human passions with a simple ferocity." "They are strange reading," he states, "in these days of the mealy-mouth, the prude and the hypocrite." The reviewer goes on to discuss the numerous variants of each ballad, as many as fourteen in one case. The reviewer of Crane's Old Ballads. A Selection from French Popular Ballads also decries the "degradation of the popular song" in the modern era and notes the number of "variants" of each ballad. About the subject of the French ballad he states, "It is hardly ever didactic and never prolix. Its lyrical character is nearly always more decided than the structure of its narrative. The latter is often fragmentary and suggested rather than expressed. ..." And, perhaps most significantly, the critic relating the talk by the Rev. Richard G. Moulton on "Ballad Poetry" recalls:

The lecturer pointed out that the ballad, in its earlier forms, existed for one purpose only - that of narrative. It held nothing by style, and taught no moral; it told a tale and gave all its energies to the telling. We are accustomed to hear of "ballad metre," and to think of it as identical with the "common metre" of the hymn book. In point of fact, the earlier ballads had no meter, in the modern acceptation: they were accented not by syllables but by "beats," or regular strokes of the reciter's staff. It was rather an object than otherwise, to crowd as many syllables as possible between beat and beat. This was interestingly illustrated by comparison of verses from the old and new versions of "Chevy Chase;"|the former divided according to "beats," the latter according to syllables. 
Leaves of Grass was decried in its own mealy-mouthed, prudish, hypocritical time for a disturbingly direct depiction of human passions. Between 1855 and 1891 it contained numerous variants of individual poems and parts of poems. Whitman seldom descended to the didactic. ${ }^{18}$ The manner of the American bard was at once lyrical and narrative, vacillating between the two modes with, for its day, alarming rapidity and regularity. And in meter, Leaves of Grass is much closer to the "ancient" ballad form, emphasizing beats rather than syllables, than it is to Scott's Border Minstrelsy. Thus, Whitman surely saw his one great organic work as in some measure returning to the traditional ballad, the origin of the song of the folk before Scott and the nineteenth-century emphasis on linear history. Scott was the first to collect and enshrine the national folk ballad. But Whitman went further, returning to the roots of folk expression - narrative and lyrical; direct, unadorned, and passionate; ever-evolving. Speaking to Traubel, Whitman is evocative about the attraction of the Border Minstrelsy. The two friends had been discussing the subject of Irish poetry. Traubel records Whitman: "The poetry was deeply fascinating: there was something even wild, even barbaric, in it: it attracted me, fascinated me, like the border minstrelsy-Scott's-seeming to contain the same elements of virile emotionalism."19 Virile emotionalism seems a particularly accurate way of describing the ballads in Scott's collection, and the same emotionalism found its way, of course, into Whitman's verse.

But it was not only the ballads Scott recorded-the Border Minstrelsybut the poetry which he wrote that Whitman enjoyed. He read Scott's own work as a young man, and kept reading him when he was old. Whitman tells in Specimen Days of a rainy day in Missouri in 1879, during which he tried a "big volume ... . of 'Milton, Young, Gray, Beattie and Collins,' but giving it up for a bad job-enjoying however for awhile, as often before, the reading of Walter Scott's poems, 'Lay of the Last Minstrel,' 'Marmion,' and so on -."20 And ten years later, speaking to Traubel on 30 December 1889, Whitman proclaims that Scott's manner in his own poems "is so free, so high-has itself so grandly the ring of balladry." 21 "The Lay of the Last Minstrel," today, seems to combine a wildly gothic story-full of evil dwarves, mysterious wizards, cursed books, fell enchantresses-with a poetic gift which has perhaps too much facility for its own good. But even in a work so very obviously different from Whitman's, perhaps it is possible to discover some seeds which might find fertile ground in the young poet's mind.

The tale is chivalric, a remnant of a bygone age told by a minstrel who is himself just such a remnant. He proceeds to enchant his audience with this thrilling story, breaking in periodically to observe the reactions of his listeners or to interpolate a thought. Just one interpolation, in fact, is the famous apostrophe to the poet's native country, familiar to many generations of grade-school students: 
Breathes there a man, with soul so dead,

Who never to himself hath said,

This is my own, my native land!

Whose heart hath ne'er within him burn'd,

As home his footsteps he hath turn'd,

From wandering on a foreign strand! (347)

If this seems like Whitman's conventional patriotic poetry from his soap-box editorial days, the next stanza seems like the later Whitman's statements about Paumanok, sung to a more conventional tune. Scott's minstrel sings:

\author{
O Caledonia! stern and wild, \\ Meet nurse for a poetic child! \\ Land of brown heath and shaggy wood, \\ Land of the mountain and the flood, \\ Land of my sires! what mortal hand \\ Can e'er untie the filial band, \\ That knits me to thy rugged strand! (347)
}

"I strike up for a New World," Whitman tells us in "Starting from Paumanok." He begins: "Starting from fish-shape Paumanok where I was born,/ Well-begotten and rais'd by a perfect mother," and proceeds through an inventory of his country and an itinerary of his life which becomes a celebration of himself and his country. Section 14 is a sustained series of apostrophes, much like Scott's but much longer.

Land of coal and iron! land of gold! land of cotton, sugar, rice!

Land of wheat, beef, pork! land of wool and hemp! land of the apple and the grape!

Land of the pastoral plains, the grass-fields of the world!

Land of those sweet-air'd interminable plateaus!

And so on. Thus the infant muse learns its native praise. In fact, this exclamatory mode becomes second nature to Whitman, often used to great effect: "Flood-tide below me! I see you face to face!," the triumphant opening to "Crossing Brooklyn Ferry," is one of the finest examples.

As "Caledonia" is somehow more poetic to Scott than the word "Scotland," so Whitman substitutes Paumanok for Long Island, Mannahatta for New York City, and other frequently more curious choices. But Scott uses his substitution to evoke the national past, while Whitman uses his to create a new native present. Indeed, "The Lay of the Last Minstrel" is in some ways a celebration of Scott's family past - there is a Sir Walter Scott in the poem and also the learned wizard Michael Scott, guardian of the magic spells - which becomes a celebration of the Scottish national past, with the author Sir Walter reciting the spells that bring the past to light. In the same way, Whitman celebrates the present grandeur and potential greatness of America by cataloguing glories which somehow have himself at the center-Paumanok, and 
America itself, become the "perfect mother," a womb in which the embryonic poet (fish-shaped, like Paumanok) develops.

Whitman, while acknowledging Scott's charm for him, finally denies his example. In "A Backward Glance ... ." Whitman tells us:

For grounds for "Leaves of Grass," as a poem, I abandon'd the conventional themes, which do not appear in it: none of the stock ornamentation, or choice plots of love or war, or high, exceptional personages of Old-World song; nothing, as I may say, for beauty's sake-no legend, or myth, or romance, nor euphemism, nor rhyme. But the broadest average of humanity and its identities in the now ripening Nineteenth Century, and especially in each of their countless examples and practical occupations in the United States to-day. ${ }^{22}$

But the poet in his age returned to Scott, rereading the poetry, as on that rainy night in Missouri, or, as Traubel tells us, exhorting the publishers for a "typographically readable" copy of the novels. He was delighted when they sent him two of his favorites. "But Scott I can take up every year-The Antiquary and The Heart of Mid-lothian in particular," the old poet tells Traubel. ${ }^{23}$ The "Virile emotionalism" he found in Scott satisfied him to the end; a phrase echoed by Sir Leslie Stephen, who wrote of Scott's novels, "The manliness and sweetness of the man's nature predispose us to render the most favourable verdict in our power." 24 We can imagine Whitman's renewed interest in The Antiquary-his tenderness for Lovel, his admiration for Oldbuck, perhaps even recognizing something of himself in the wandering, shaman-like Edie Ochiltree. We can imagine, too, the solemn mood reading the description of Steenie Mucklebackit's funeral, for, like Housman, Whitman was greatly moved by the deaths of young men. Perhaps Sir Leslie's daughter Virginia Woolf captured their feeling most vividly, however, when she portrayed Mr. Ramsey sitting in the library rereading Scott and thinking:

This man's strength and sanity, his feeling for straightforward simple things, these fishermen, the poor old crazed creature in Mucklebackit's cottage made him feel so vigorous, so relieved of something that he felt roused and triumphant and could not choke back his tears. Raising the book a little to hide his face, he let them fall and shook his head from side to side and forgot himself completely ... forgot his own bothers and failures completely in poor Steenie's drowning and Mucklebackit's sorrow (that was Scott at his best) and the astonishing delight and feeling of vigour that it gave him. ${ }^{25}$

So Whitman can say to Traubel as they discuss Robert Louis Stevenson's inability to understand Scott, "How could he? ... Scott was too simple, too natural, for him. Scott had a great love for the medieval-persons, equipage, what-not-a real love, running in him deep; yet was as free as a child-loved to get out in the air, breathe, grow, commune with nature-a splendid, healthy personality." 26 Vigor, manliness, and the natural and simple freedom of a child - these were for Whitman attributes linking him with Scott.

Whitman in his poetry often addresses the poets of the future, eloquently 
and convincingly, and perhaps his demands have been met. About the poets of the past, however, he was not able or willing to write so eloquently. A manuscript fragment-broken off after six lines-addresses the old world poets; it seems to evoke both something of Whitman's feeling for Scott, and something of the older poet's deepest similarity with the New World bard. Whitman writes:

\section{America to the Old World Bards}

Be thy task for once to thank in my name, the old world Bards And be thy task to speak in my name to preserve the antique poems

Let them pass through

Let the phantoms walk the roads of thy soul

Call up the pale great

Let the procession pass-let the shadow walk through the very soul27

At the height of his creative career Whitman may have condemned the politics and poetic manner of Scott. But in Border Minstrelsy, as Lockhart reminds us, Scott found the subjects for his later romances written in both poetry and prose. And in Border Minstrelsy, Whitman recognized a model for Leaves of Grass. The organic evolution and wholeness of his great collection both recreates and transforms Scott's ballads. The people of America are subsumed in their bard and sing through him. Thus the soul of the baronet-imbued with the particular, with his nation, with the ballads and the hearts of its folk, with a virile and honest and open manliness, with childlike freedom and simplicity-speaks again through the soul of the American bard. It is a fortunate confluence of voices.

\section{Davidson College}

\section{NOTES}

1 Justin Kaplan, Walt Whitman: A Life (New York: Simon and Schuster, 1980), 17.

2 Walt Whitman, “'Home' Literature,” The Gathering of Forces, 1846-1847, ed. Cleveland Rodgers and John Black (New York: G. P. Putnam's Sons, 1920), 2:243.

3 Paul Zweig, Walt Whitman: The Making of a Poet (New York: Basic Books, 1984), 42-43.

4 Horace Traubel, With Walt Whitman in Camden (New York: Rowman and Littlefield, 1961), 1:96.

5 Traubel, 1:235.

6 Floyd Stovall, The Foreground of "Leaves of Grass" (Charlottesville: University Press of Virginia, 1974), 100.

7 Stovall, 50.

8 Walt Whitman, Prose Works 1892, ed. Floyd Stovall (New York: New York University Press, 1963), 2:722.

9 Traubel, 1:35. 
10 Sir Walter Scott, The Complete Works of Sir Walter Scott (New York: Conner \& Cooke, 1833), I. All further references to this edition and to Whitman's marginal comments and underlinings in his copy of this edition will appear in the text. Mr. Charles E. Feinberg has told me that he bought Whitman's copy of this volume in the late 1940s from Mrs. Gertrude Traubel, daughter of Horace and Anne Montgomery Traubel. It was, therefore, owned by only Whitman (and perhaps someone else between 1833 and 1835), the Traubels, and Feinberg before it became part of the Feinberg Collection in the Library of Congress. Whitman's holograph title page is reproduced on the back cover, and the first of his Table of Contents pages is reproduced within this essay; both are courtesy of the Library of Congress.

11 In The Ecstatic Whitman: Literary Shamanism and the Crisis of the Union (Columbus: Ohio State University Press, 1986), George B. Hutchinson correctly states that Whitman's edition of the Minstrelsy of the Scottish Border also contained "Letters on Demonology and Witchcraft." Hutchinson briefly suggests that Whitman may have been especially interested in Scott's depiction of "witchcraft" in the Border Minstrelsy and his discussion of the "eidolon" in "Letters on Demonology and Witchcraft" (43). Both of Hutchinson's suggestions seem likely. But none of Whitman's marginalia or underlining in the Border Minstrelsy draws explicit attention to witchcraft, and Whitman made not a single mark in "Letters on Demonology and Witchcraft."

12 Stovall, 178.

13 All quotations from "Song of Myself" are taken from Leaves of Grass: A Textual Variorum of the Printed Poem, 3 vols., ed. Sculley Bradley, Harold W. Blodgett, Arthur Golden, and William White (New York: New York University Press, 1980).

14 Whitman, Prose Works, 2:476.

15 Walter Morris Hart, Ballad and Epic: A Study in the Development of the Narrative Art, Volume 11 in Studies and Notes in Philology and Literature (Boston: Ginn \& Co., 1907), 34.

16 Hart, 41.

17 Hart, 45-46.

18 On 6 February 1890, Whitman spoke to Traubel about the nature of the truth. Whitman suggested that "[t]he question would appear to be relative," and went on to note that they were on "debatable ground." He then said, "The great story-tellers - the writers - say Walter Scott, whose genius for taking us on the borderline of questions was great, superb, beyond precedent-are not eager to use situations of obvious results, decisions, but those that can excite divergence of judgment" (Traubel, 6:286-287). Thus Whitman stresses the nondidactic quality of Scott's work and, by implication, of his own. His comment on the "borderline of questions" is almost surely a rather sly reference to Border Minstrelsy and perhaps to the complex treatment of truth and judgment in the ballad form.

19 Traubel, 4:86.

20 Whitman, Prose Works, 1:222.

21 Traubel, 6:222-223.

22 Whitman, Prose Works, 2:715.

23 Traubel, 2:391.

24 Leslie Stephen, Hours in a Library (New York: G. P. Putnam's Sons, 1899), 1:139.

25 Virginia Woolf, To the Lighthouse (New York: Harcourt, Brace \& Co., 1927), 179-180.

26 Traubel, 6:205.

27 Leaves of Grass: A Norton Critical Edition, ed. Sculley Bradley and Harold W. Blodgett (New York: Norton, 1973), 688. 